\title{
STATISTICAL-MATHEMATICAL PROCESSING OF ANTHROPOMETRIC FOOT PARAMETERS AND ESTABLISHING SIMPLE AND MULTIPLE CORRELATIONS. PART 1: STATISTICAL ANALYSIS OF FOOT SIZE PARAMETERS
}

\author{
Mirela PANTAZI ${ }^{1 *}$, Ana Maria VASILESCU ${ }^{1}$, Aura MIHAI ${ }^{2}$, Dana GURĂU ${ }^{1}$ \\ ${ }^{1}$ INCDTP - Division: Leather and Footwear Research Institute, 93 Ion Minulescu, 031215 Bucharest, Romania, pantazimirela@ \\ yahoo.com
}

${ }^{2}$ Gheorghe Asachi Technical University of lasi, 67 Dimitrie Mangeron Blvd., lasi, Romania, amihai@tex.tuiasi.ro

Received: 19.09.2017 Accepted: 20.11.2017

https://doi.org/10.24264/lfj.17.4.3

\section{STATISTICAL-MATHEMATICAL PROCESSING OF ANTHROPOMETRIC FOOT PARAMETERS AND ESTABLISHING SIMPLE AND MULTIPLE CORRELATIONS. PART 1: STATISTICAL ANALYSIS OF FOOT SIZE PARAMETERS}

ABSTRACT. The purpose of this study is to evaluate anthropometric parameters resulting from measurements by their statistical and mathematical processing. The study was conducted on a sample of 300 male subjects from three geographic regions of Romania: South (100 subjects), East (100 subjects) and Centre and West (100 subjects). The anthropometric data collected by 3D scanning of the left and right foot were grouped into four samples (South, East, Centre-West and Total) and the statistical indicators of characterization (arithmetic mean and standard deviation) and statistical variables (the minimum and maximum values, the amplitude and the coefficient of variation) were calcuated for each variational sequence of the 20 anthropometric parameters studied. To verify the working hypothesis that there were no significant differences between left and right foot, Student's t-test and the Fisher (F) test were used to verify the variants. Both tests have shown that there are no significant differences between the left foot and the right foot for most anthropometric parameters. Samples for the four groups studied were based on the average of anthropometric parameters of the right and left foot. One-dimensional normal-size distribution for Foot Length (Lp) and Toe Girth (Pd) anthropometric parameters was verified. In this respect, the limits of the frequency classes, the centre of the class and the relative and absolute frequencies were established. This distribution is found in the commissioning of the shoe size series. For an optimal fit of the shoe, it is necessary to divide the size series into length and width classes.

KEY WORDS: anthropometric parameters, foot, statistical indicators

\section{PRELUCRAREA STATISTICO-MATEMATICĂ A PARAMETRILOR ANTROPOMETRICI AI PICIORULUI ŞI STABILIREA CORELATIILOR SIMPLE ŞI} MULTIPLE. PARTEA 1: ANALIZA STATISTICĂ A PARAMETRILOR DIMENSIONALI AI PICIORULUI

REZUMAT. Scopul acestui studiu constă în evaluarea parametrilor antropometrici rezultaţi din măsurători, prin prelucrarea statisticomatematică a acestora. Studiul a fost efectuat pe un eşantion format dintr-un număr de 300 subiecţi, sex masculin, din trei regiuni geografice ale României: Sud (100 subiecţi), Est (100 subiecţi) şi Centru şi Vest (100 subiecţi). Au fost grupate datele antropometrice prelevate prin scanarea 3D a piciorului stâng, respectiv drept, în patru eşantioane (Sud, Est, Centru-Vest şi Total) şi au fost calculaţi indicatorii statistici de caracterizare (media aritmetică şi abaterea standard) şi indicatorii statistici de variaţie (valoarea minimă şi cea maximă, amplitudinea şi coeficientul de variaţie) pentru fiecare şir variational ai celor 20 de parametri antropometrici studiaţi. Pentru verificarea ipotezei de lucru conform căreia nu există diferenţe semnificative între piciorul stâng şi piciorul drept, s-a utilizat testul t Student, iar pentru verificarea variantelor s-a utilizat testul Fisher (F). Ambele teste au demonstrat că nu există diferenţe semnificative între piciorul stâng şi piciorul drept pentru majoritatea parametrilor antropometrici. S-au constituit eşantione pentru cele patru grupuri studiate în baza mediilor parametrului antropometric

pentru piciorul drept şi piciorul stâng. A fost verificată repartiţia unidimensională de tip normal pentru parametrii antropometrici Lungimea piciorului (Lp) şi Perimetrul la degete (Pd). În acest sens, au fost stabilite limitele claselor de frecvenţă, centrul clasei şi frecvenţele relativă şi absolută. Această repartiţie se regăseşte în formarea comisioanelor la stabilirea seriei de mărimi a încălţămintei. Pentru o potrivire optimă a încălţămintei este necesar ca seria de mărimi să fie împărţită pe clase de lungimi şi lărgimi.

CUVINTE CHEIE: parametri antropometrici, picior, indicatori statistici

LE TRAITEMENT STATISTIQUE-MATHÉMATIQUE DES PARAMÈTRES ANTROPOMÉTRIQUES DU PIED ET LA DÉTERMINATION DES CORRÉLATIONS SIMPLES ET MULTIPLES. PREMIÈRE PARTIE : L'ANALYSE STATISTIQUE DES PARAMÈTRES DIMENSIONNELS DU PIED

RÉSUMÉ. Le but de cette étude est d'évaluer les paramètres anthropométriques résultant des mesures, par leur traitement statistique et mathématique. L'étude a été réalisée sur un échantillon de 300 sujets masculins de trois régions géographiques de la Roumanie: Sud (100 sujets), Est (100 sujets) et Centre et Ouest (100 sujets). Les données anthropométriques recueillies par le balayage 3D du pied gauche et du pied droit ont été regroupées en quatre échantillons (Sud, Est, Centre-Ouest et Total) et les indicateurs statistiques de caractérisation (moyenne arithmétique et écart-type) et les variables statistiques (les valeurs minimale et maximale, l'amplitude et le coefficient de variation) ont été calculés pour chaque séquence variationnelle des 20 paramètres anthropométriques étudiés. Pour vérifier l'hypothèse de travail selon laquelle il n'y avait pas de différence significative entre le pied gauche et le pied droit, le test-t de Student et le test de Fisher (F) ont été utilisés pour vérifier les variantes. Les deux tests ont montré qu'il n’y avait pas de différence significative entre le pied gauche et le pied droit pour la plupart des paramètres anthropométriques. Les échantillons pour les quatre groupes étudiés ont été basés sur la moyenne anthropométrique du pied droit et du pied gauche. La distribution de taille normale unidimensionnelle pour les paramètres anthropométriques de longueur du pied (Lp) et de périmètre aux orteils ( $\mathrm{Pd}$ ) a été vérifiée. À cet égard, les limites des classes de fréquence, du centre de la classe et des fréquences relative et absolue ont été établies. Cette distribution se trouve dans la mise en service de la série de chaussures. Pour un ajustement optimal de la chaussure, il est nécessaire de diviser les séries de tailles en classes de longueur et de largeur. MOTS CLÉS : paramètres anthropométriques, pied, indicateurs statistiques

\footnotetext{
* Correspondence to: Mirela PANTAZI, INCDTP - Division: Leather and Footwear Research Institute, 93 lon Minulescu, 031215 Bucharest, Romania, pantazimirela@yahoo.com
} 


\section{INTRODUCTION}

Manufacturing comfortable footwear relies on anthropometric research, which determines the morphological character of the foot, the behavior of the foot-footwear system and the results of the morpho-functional optimization of the shape of the product.

The natural anatomic-morphological construction of the foot, its correct static and dynamic functioning is ensured by a rational inner shape of the shoe, the shape which is determined in turn by the construction of the last.

The construction of the last, the establishment of the dimensions required to meet the comfort requirements of a larger proportion of consumers with minimal production costs, must be based on the knowledge and the most accurate characterization of the anatomicmorphological differences of the types of foot encountered within that population of consumers and the frequency of these types within the population.

For this purpose, it is periodically necessary to perform anthropometric studies on the population differentiated according to certain criteria (sex, age, geographical region, etc.) in order to obtain information about the dimensional particularities of the average representative foot for that population, the laws of distribution of anthropometric parameters that characterize the representative average foot of the population of the respective country.

All this information will be used directly for the rational dimensioning of lasts to solve two important aspects: on the one hand the standardization of the shape and the dimensions of the last, i.e. finding the optimal relationship between the dimensions of the separate parts based on the construction of real biometric models of the wearer's foot and the variation of its dimensional characteristics within the population in order to define the particular foot sizes of the population, and on the other hand, the calculation of the percentage distribution of the footwear corresponding to a particular size of the wearer's foot (defining tallies of sizes and widths).

Tallies of serial production must match the shape and the internal dimensions of the shoe given by the last and the shape and dimensions of the foot of the majority of wearers.

The values of the anthropometric parameters reveal the dimensional changes of the foot depending on gender, age, geographical conditions.

Anthropometric data sampling can be done using two measurement methods:

- by direct contact with the foot to be measured, where the values are measured and recorded manually;

- by collecting anthropometric data without direct contact, in which case the foot conformation and dimensions are obtained through 3D scanning systems that allow storage and processing of data with specialized software.

The correlation of the inner dimensions of the shoe with the anthropometric dimensions of the foot is particularly important in order to meet the comfort conditions, the most representative being: toe width, toe height, heel breadth, and foot length.

The purpose of this study is to evaluate anthropometric parameters resulting from the measurements by means of their statistical and mathematical processing.

\section{EXPERIMENTAL}

\section{Materials and Methods}

The 3D foot shape based on which anthropometric parameters are measured was scanned using the INFOOT USB system (Figure 1) made up of the 3D scanner and the dedicated MEASURE 2.8 software. The system enables foot shape scanning and can automatically recognize and place up to 20 anatomical measurement points.

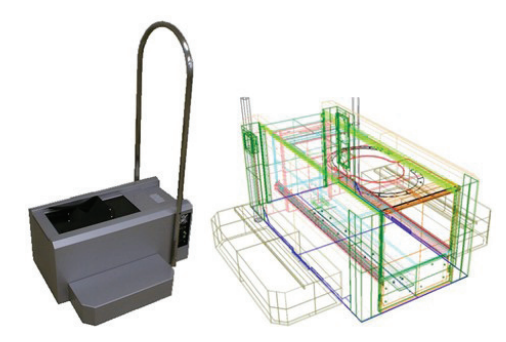

Figure 1. INFOOT USB 3D Scanner 
Foot shape scanning and placement of anatomical points on the surface of the scanned foot shape enabled determination of values for a set of 20 anthropometric parameters, lengths, widths, girths and angles (Table 1) [1].

Table 1: Analysed anthropometric foot parameters

\begin{tabular}{llll}
\hline 1. & Foot length & $\mathrm{Lp}$ & $(\mathrm{mm})$ \\
2. & Ball girth circumference & $\mathrm{Pd}$ & $(\mathrm{mm})$ \\
3. & Foot breadth & $\mathrm{Id}$ & $(\mathrm{mm})$ \\
4. Instep circumference & $\mathrm{Pr}$ & $(\mathrm{mm})$ \\
5. Heel breadth & $\mathrm{Ic}$ & $(\mathrm{mm})$ \\
6. Instep length & $\mathrm{Lr}$ & $(\mathrm{mm})$ \\
7. Toe height & $\mathrm{Hd}$ & $(\mathrm{mm})$ \\
8. Instep height & $\mathrm{Hr}$ & $(\mathrm{mm})$ \\
9. Toe 1 angle & $\mathrm{Ud} 1$ & $\left({ }^{\circ}\right)$ \\
10. Toe 5 angle & $\mathrm{Ud} 5$ & $\left({ }^{\circ}\right)$ \\
11. Toe 1 height & $\mathrm{Hd} 1$ & $(\mathrm{~mm})$ \\
12. Toe 5 height & $\mathrm{Hd} 5$ & $(\mathrm{~mm})$ \\
13. Height of navicular & $\mathrm{Hn}$ & $(\mathrm{mm})$ \\
14. Height of Sphyrion fibulare & $\mathrm{Hsf}$ & $(\mathrm{mm})$ \\
15. Height of Sphyrion & $\mathrm{Hs}$ & $(\mathrm{mm})$ \\
16. Height of the most lateral point of & $\mathrm{Hme}$ & $(\mathrm{mm})$ \\
17. Height of the most medial point of & $\mathrm{Hmi}$ & $(\mathrm{mm})$ \\
18. Heel angle & $\mathrm{Uc}$ & $\left({ }^{\circ}\right)$ \\
19. Heel girth & $\mathrm{Pc}$ & $(\mathrm{mm})$ \\
20. Ankle girth & $\mathrm{Pg}$ & $(\mathrm{mm})$ \\
\hline
\end{tabular}

Anthropometric footprints obtained using the INFOOT USB system were statistically analyzed using the SPSS software package, which is a package dedicated to statistical data processing, making it easy to obtain the desired results quickly.

\section{Subjects}

Anthropometric studies were conducted on a sample of 300 male subjects from three geographic regions of Romania: South (100 subjects), East (100 subjects), and Centre and West (100 subjects). Subjects with particular anthropometric features, including deformities and structural abnormalities of the foot, were excluded.

\section{RESULTS AND DISCUSSIONS}

\section{Verifying the Statistical Significance of Differences between Anthropometrical Parameters of the Left and Right Foot Using}

\section{Student Test and Fisher Test}

Student's t-test was used to test the working hypothesis that there are no significant differences between left and right foot. The test determines the associated probability to determine if two samples are likely to come from the same two basic populations that have the same mean. The research hypothesis in the case of the group of subjects is represented by the statistical significance of the recorded values for the left and right foot compared to the mean values for the left and right foot. The $T$ test confirms whether there is a significant difference between these values. This will allow the use of mean values in establishing correlations and variation laws by building samples based on the mean value of the antropometric parameter associated to the left foot and the one associated to the right foot.

To determine whether the results obtained are statistically significant, the calculated values are compared to $p=0.05$ for a $95 \%$ probability. To confirm the null hypothesis, the $p$ values must be greater than $p=0.05$.

The results of the Student's Test are presented in Table 2. T test values lower than the significance threshold of 0.05 are indicated for the following anthropometric parameters: instep height $(\mathrm{Hr})$, toe 1 height $(\mathrm{Hd} 1)$, height of navicular $(\mathrm{Hn})$, height of Sphyrion fibulare (Hsf), height of the most lateral point of lateral malleolus ( $\mathrm{Hme}$ ), heel angle (Uc), and ankle girth $(\mathrm{Pg})$. For the other anthropometric parameters, the null hypothesis is confirmed, according to which there are no statistically significant differences between the means of the studied parameters.

The Fisher test was used to verify that variants in the matrix of anthropometric parameters for the left foot did not differ significantly from the variants of the right foot matrix values. The values obtained for the $F$ test are shown in Table 2.

The analysis of the values obtained by applying the two types of tests results in the rejection of the null hypothesis, and consequently the existence of significant differences between the right and the left foot in the case of one anthropometric parameter, namely the height of Sphyrion fibulare (Hsf). 
Table 2: $\mathrm{T}$ (student) test and $\mathrm{F}$ (Fisher) test

\begin{tabular}{|c|c|c|c|c|}
\hline & Anthropometric parameters & & T test & F test \\
\hline 1. & Foot length & Lp & 0.317589 & 0.564553 \\
\hline 2. & Ball girth circumference & $\mathrm{Pd}$ & 0.338263 & 0.483241 \\
\hline 3. & Foot breadth & Id & 0.101553 & 0.319551 \\
\hline 4. & Instep circumference & $\operatorname{Pr}$ & 0.298322 & 0.63871 \\
\hline 5. & Heel breadth & Ic & 0.416227 & 0.680185 \\
\hline 6. & Instep length & $\operatorname{Lr}$ & 0.005163 & 0.259382 \\
\hline 7. & Toe height & $\mathrm{Hd}$ & 0.381454 & 0.83237 \\
\hline 8. & Instep height & $\mathrm{Hr}$ & 4.07E-05 & 0.830783 \\
\hline 9. & Toe 1 angle & Ud1 & 0.067916 & 0.116667 \\
\hline 10. & Toe 5 angle & Ud5 & 0.083654 & $2.4 \mathrm{E}-274$ \\
\hline 11. & Toe 1 height & $\mathrm{Hd} 1$ & 0.02601 & 0.730987 \\
\hline 12. & Toe 5 height & Hd5 & 0.145579 & 0.058903 \\
\hline 13. & Height of navicular & $\mathrm{Hn}$ & $8.66 \mathrm{E}-23$ & 0.643273 \\
\hline 14. & Height of Sphyrion fibulare & Hsf & 0.001586 & 0.009536 \\
\hline 15. & Height of Sphyrion & Hs & 0.059013 & 0.660882 \\
\hline 16. & Height of the most lateral point of lateral malleolus & Hme & 0.001909 & 0.102374 \\
\hline 17. & Height of the most medial point of medial malleolus & $\mathrm{Hmi}$ & 0.262626 & 0.800037 \\
\hline 18. & Heel angle & Uc & $2.22 \mathrm{E}-07$ & 0.398818 \\
\hline 19. & Heel girth & Pc & 0.114933 & 0.863741 \\
\hline 20. & Ankle girth & $\mathrm{Pg}$ & 0.020876 & 0.475921 \\
\hline
\end{tabular}

\section{Statistical Indicators of Characterization and Variation of Anthropometric Parameters}

The main calculated statistical indicators are arithmetic mean $(\bar{x} \bar{x})$, standard deviation $(\mathrm{S})$, sample dispersion $\left(\mathrm{S}^{2}\right)$, minimum, maximum, variance amplitude (A) and coefficient of variation (CV). The statistical indicators for characterization and variation of the calculated anthropometric parameters are presented in Table 3.

Arithmetic mean $(\bar{x} \bar{x})$ represents the central trend of statistical selection, it can be strongly influenced by extreme values and reflects the values of the entire variational sequence. The arithmetic mean $(\bar{x})$, for the unmatched data (simple series) $[2,3,4]$ is calculated with the relation:

$$
\bar{x}=\frac{\sum_{i=1}^{n} x_{i}}{n}
$$

where: $\sum_{i=1}^{n} x_{i} \sum_{i=1}^{n} x_{i}=$ sum of scores; $n n=$ total number of scores.

Dispersion is how the values in the series revolve around the series. This is calculated as an arithmetic mean of squares of deviations from their arithmetic mean $[5,6]$. For simple series:

$$
S^{2}=\frac{\sum_{i=1}^{n}\left(x_{i}-\bar{x}\right)^{2}}{n}
$$

The standard deviation represents the degree of scattering of the series values compared to the mean. This is the square root of the dispersion value, which indicates how much the values of the series deviate from their arithmetic mean $[7,8,9]$. For simple series:

$$
S=\sqrt{\frac{\sum_{i=1}^{n}\left(x_{i}-\bar{x}\right)^{2}}{n}}
$$

The amplitude of the variation is the difference between the maximum value and the minimum value of a distribution and indicates the value range of the distribution. The amplitude is obtained by the difference between the maximum value and the minimum value of the series values and is calculated by the formula $[10,11,12]$ :

$$
A=x_{\max }-x_{\min }
$$

Coefficient of variation (CV\%) - refers to the degree of scattering of values in a series around the mean. It is defined as the ratio of 
the standard deviation of a distribution and its arithmetic mean [13]. It is used to analyze the degree of scattering of a distribution.

$$
C V=\frac{S}{\bar{x}} * 100(\%)
$$

- If $\mathrm{CV}<15 \%$ then the scattering is small the case of most anthropometric parameters;
- If $15 \%<C V<30 \%$, scattering is medium - these situations are highlighted in yellow in Table 3;

- If $\mathrm{CV}>30 \%$ then scattering is high - these situations are highlighted in red in Table 3.

The statistical indicators for characterization and variation of the calculated anthropometric parameters are presented in Table 3.

Table 3: Statistical indicators of characterization of anthropometric parameters

\begin{tabular}{|c|c|c|c|c|c|c|c|c|c|c|}
\hline No. & $\begin{array}{c}\text { Anthropometric } \\
\text { parameters }\end{array}$ & Group & $\begin{array}{c}\text { No. of } \\
\text { subjects }\end{array}$ & $\begin{array}{c}\bar{x} \\
(\mathrm{~mm})\end{array}$ & $\begin{array}{c}\mathrm{S} \\
(\mathrm{mm})\end{array}$ & $\begin{array}{c}\mathrm{S}^{2} \\
\left(\mathrm{~mm}^{2}\right) \\
\end{array}$ & $\begin{array}{l}\text { Min } \\
(\mathrm{mm})\end{array}$ & $\begin{array}{l}\text { Max } \\
(\mathrm{mm})\end{array}$ & $\begin{array}{c}A \\
(\mathrm{~mm})\end{array}$ & $\begin{array}{l}\text { CV } \\
(\%) \\
\end{array}$ \\
\hline \multirow{4}{*}{1} & \multirow{4}{*}{ Lp } & South & 100 & 259.70 & 21.28 & 453.01 & 244.65 & 274.75 & 30.10 & 8.20 \\
\hline & & East & 100 & 263.25 & 17.96 & 322.58 & 250.55 & 275.95 & 25.40 & 6.82 \\
\hline & & Centre and West & 100 & 280.78 & 6.82 & 46.56 & 275.95 & 285.60 & 9.65 & 2.43 \\
\hline & & Total & 300 & 267.43 & 13.15 & 172.81 & 229.05 & 302.50 & 73.45 & 4.92 \\
\hline \multirow{4}{*}{2} & \multirow{4}{*}{$\mathrm{Pd}$} & South & 100 & 275.13 & 11.14 & 124.03 & 267.25 & 283.00 & 15.75 & 4.05 \\
\hline & & East & 100 & 258.95 & 4.74 & 22.45 & 255.60 & 262.30 & 6.70 & 1.83 \\
\hline & & Centre and West & 100 & 271.45 & 12.94 & 167.45 & 262.30 & 280.60 & 18.30 & 4.77 \\
\hline & & Total & 300 & 261.09 & 13.28 & 176.49 & 217.60 & 297.35 & 79.75 & 5.09 \\
\hline \multirow{4}{*}{3} & \multirow{4}{*}{ Id } & South & 100 & 111.45 & 4.60 & 21.13 & 108.20 & 114.70 & 6.50 & 4.12 \\
\hline & & East & 100 & 105.98 & 0.18 & 0.03 & 105.85 & 102.50 & 0.25 & 0.17 \\
\hline & & Centre and West & 100 & 110.88 & 7.11 & 50.50 & 105.85 & 115.90 & 10.05 & 6.41 \\
\hline & & Total & 300 & 106.89 & 5.73 & 32.78 & 87.35 & 122.00 & 34.65 & 5.36 \\
\hline \multirow{4}{*}{4} & \multirow{4}{*}{$\mathrm{Pr}$} & South & 100 & 311.95 & 52.11 & 2715.85 & 275.10 & 348.80 & 73.70 & 16.71 \\
\hline & & East & 100 & 264.03 & 4.42 & 19.53 & 260.90 & 267.15 & 6.25 & 1.67 \\
\hline & & Centre and West & 100 & 268.08 & 1.31 & 1.71 & 267.15 & 269.00 & 1.85 & 0.49 \\
\hline & & Total & 300 & 263.31 & 15.00 & 225.02 & 224.75 & 348.80 & 124.05 & 5.70 \\
\hline \multirow{4}{*}{5} & \multirow{4}{*}{ Ic } & South & 100 & 72.13 & 1.73 & 3.00 & 70.90 & 73.35 & 2.45 & 2.40 \\
\hline & & East & 100 & 68.23 & 2.72 & 7.41 & 66.30 & 70.15 & 3.85 & 3.99 \\
\hline & & Centre and West & 100 & 71.90 & 2.47 & 6.13 & 70.15 & 73.65 & 3.50 & 3.44 \\
\hline & & Total & 300 & 69.98 & 3.96 & 15.70 & 59.95 & 84.60 & 24.65 & 5.66 \\
\hline \multirow{4}{*}{6} & \multirow{4}{*}{$\mathrm{Lr}$} & South & 100 & 186.63 & 13.19 & 173.91 & 177.30 & 195.95 & 18.65 & 7.07 \\
\hline & & East & 100 & 191.40 & 14.07 & 198.01 & 181.45 & 201.35 & 19.90 & 7.35 \\
\hline & & Centre and West & 100 & 202.73 & 1.94 & 3.78 & 201.35 & 204.10 & 2.75 & 0.96 \\
\hline & & Total & 300 & 191.86 & 10.02 & 100.31 & 157.25 & 218.10 & 60.85 & 5.22 \\
\hline \multirow{4}{*}{7} & \multirow{4}{*}{$\mathrm{Hd}$} & South & 100 & 163.33 & 13.19 & 173.91 & 154.00 & 172.65 & 18.65 & 8.07 \\
\hline & & East & 100 & 168.80 & 10.96 & 120.13 & 161.05 & 176.55 & 15.50 & 6.49 \\
\hline & & Centre and West & 100 & 180.18 & 5.13 & 26.28 & 176.55 & 183.80 & 7.25 & 2.85 \\
\hline & & Total & 300 & 169.03 & 8.46 & 71.54 & 142.30 & 188.80 & 46.50 & 5.00 \\
\hline
\end{tabular}




\begin{tabular}{|c|c|c|c|c|c|c|c|c|c|c|}
\hline \multirow{4}{*}{8} & \multirow{4}{*}{$\mathrm{Hr}$} & South & 100 & 51.95 & 0.00 & 0.00 & 51.95 & 51.95 & 0.00 & 0.00 \\
\hline & & East & 100 & 44.75 & 3.25 & 10.58 & 42.45 & 47.05 & 4.60 & 7.27 \\
\hline & & Centre and West & 100 & 47.23 & 0.25 & 0.06 & 47.05 & 47.40 & 0.35 & 0.52 \\
\hline & & Total & 300 & 46.11 & 3.55 & 12.64 & 36.60 & 58.50 & 21.90 & 7.71 \\
\hline \multirow{4}{*}{9} & \multirow{4}{*}{ Ud1 } & South & 100 & 5.20 & 3.25 & 10.58 & 2.90 & 7.50 & 4.60 & 62.55 \\
\hline & & East & 100 & 7.33 & 7.81 & 61.05 & 1.80 & 12.85 & 11.05 & 106.67 \\
\hline & & Centre and West & 100 & 3.28 & 2.09 & 4.35 & 1.80 & 4.75 & 2.95 & 63.69 \\
\hline & & Total & 300 & 6.14 & 4.41 & 19.48 & -5.45 & 17.50 & 22.95 & 71.90 \\
\hline \multirow{4}{*}{10} & \multirow{4}{*}{ Ud5 } & South & 100 & 18.25 & 1.56 & 2.42 & 17.15 & 19.35 & 2.20 & 8.52 \\
\hline & & East & 100 & 13.63 & 4.91 & 24.15 & 10.15 & 17.10 & 6.95 & 36.07 \\
\hline & & Centre and West & 100 & 12.65 & 3.54 & 12.50 & 10.15 & 15.15 & 5.00 & 27.95 \\
\hline & & Total & 300 & 14.64 & 4.05 & 16.37 & 0.60 & 24.85 & 24.25 & 27.64 \\
\hline \multirow{4}{*}{11} & \multirow{5}{*}{$\mathrm{Hd} 1$} & South & 100 & 27.28 & 3.43 & 11.76 & 24.85 & 29.70 & 4.85 & 12.57 \\
\hline & & East & 100 & 24.78 & 4.56 & 20.80 & 21.55 & 28.00 & 6.45 & 18.41 \\
\hline & & Centre and West & 100 & 25.83 & 3.08 & 9.46 & 23.65 & 28.00 & 4.35 & 11.91 \\
\hline & & Total & 300 & 24.56 & 2.21 & 4.89 & 19.75 & 34.60 & 14.85 & 9.00 \\
\hline \multirow{4}{*}{12} & & South & 100 & 22.50 & 0.85 & 0.72 & 21.90 & 23.10 & 1.20 & 3.77 \\
\hline & \multirow{3}{*}{$\mathrm{Hd} 5$} & East & 100 & 20.60 & 2.26 & 5.12 & 19.00 & 22.20 & 3.20 & 10.98 \\
\hline & & Centre and West & 100 & 22.43 & 0.32 & 22.20 & 22.20 & 22.65 & 0.45 & 1.42 \\
\hline & & Total & 300 & 20.99 & 2.49 & 6.21 & 11.75 & 31.30 & 19.55 & 11.87 \\
\hline \multirow{4}{*}{13} & \multirow{4}{*}{$\mathrm{Hn}$} & South & 100 & 38.38 & 0.25 & 0.06 & 38.20 & 38.55 & 0.35 & 0.64 \\
\hline & & East & 100 & 37.88 & 0.32 & 0.10 & 37.65 & 38.10 & 0.45 & 0.84 \\
\hline & & Centre and West & 100 & 38.55 & 0.64 & 0.41 & 38.10 & 39.00 & 1.65 & 1.65 \\
\hline & & Total & 300 & 38.09 & 0.86 & 0.74 & 35.80 & 40.80 & 5.00 & 2.25 \\
\hline \multirow{4}{*}{14} & \multirow{4}{*}{ Hsf } & South & 100 & 56.23 & 10.36 & 107.31 & 48.90 & 63.55 & 14.65 & 18.42 \\
\hline & & East & 100 & 57.08 & 8.73 & 76.26 & 50.90 & 63.25 & 12.35 & 15.30 \\
\hline & & Centre and West & 100 & 62.65 & 0.85 & 0.72 & 62.05 & 63.25 & 1.20 & 1.35 \\
\hline & & Total & 300 & 58.23 & 4.51 & 20.38 & 42.90 & 69.65 & 26.75 & 7.75 \\
\hline \multirow{4}{*}{15} & \multirow{4}{*}{ Hs } & South & 100 & 57.45 & 13.44 & 180.50 & 47.95 & 66.95 & 19.00 & 23.39 \\
\hline & & East & 100 & 65.23 & 4.84 & 23.46 & 61.80 & 68.65 & 6.85 & 7.43 \\
\hline & & Centre and West & 100 & 68.45 & 0.28 & 0.08 & 68.25 & 68.65 & 0.40 & 0.41 \\
\hline & & Total & 300 & 66.43 & 5.65 & 31.89 & 45.35 & 80.85 & 35.50 & 8.50 \\
\hline \multirow{4}{*}{16} & \multirow{4}{*}{ Hme } & South & 100 & 74.83 & 11.99 & 143.65 & 66.35 & 83.30 & 16.95 & 16.02 \\
\hline & & East & 100 & 75.15 & 12.23 & 149.64 & 66.50 & 83.80 & 17.30 & 16.28 \\
\hline & & Centre and West & 100 & 83.30 & 0.71 & 0.50 & 82.80 & 83.80 & 1.00 & 0.85 \\
\hline & & Total & 300 & 77.84 & 5.24 & 27.42 & 63.85 & 92.95 & 29.10 & 6.73 \\
\hline \multirow{4}{*}{17} & \multirow{4}{*}{$\mathrm{Hmi}$} & South & 100 & 76.45 & 14.71 & 216.32 & 66.05 & 86.85 & 20.80 & 19.24 \\
\hline & & East & 100 & 85.45 & 6.51 & 42.32 & 80.85 & 90.05 & 9.20 & 7.61 \\
\hline & & Centre and West & 100 & 90.48 & 0.60 & 0.36 & 90.05 & 90.90 & 0.85 & 0.66 \\
\hline & & Total & 300 & 87.22 & 6.46 & 41.71 & 64.60 & 103.15 & 38.55 & 7.40 \\
\hline & & South & 100 & 2.30 & 2.33 & 5.45 & 0.65 & 3.95 & 3.30 & 101.45 \\
\hline 10 & 1 & East & 100 & 3.00 & 0.49 & 0.25 & 2.65 & 3.35 & 0.70 & 16.50 \\
\hline 10 & 0 & Centre and West & 100 & 1.88 & 2.09 & 4.35 & 0.40 & 3.35 & 2.95 & 111.25 \\
\hline & & Total & 300 & 3.42 & 2.47 & 6.09 & -3.75 & 9.60 & 13.35 & 72.16 \\
\hline & & South & 100 & 358.03 & 17.57 & 308.76 & 345.60 & 370.45 & 24.85 & 4.91 \\
\hline 10 & $\mathrm{D}$ & East & 100 & 338.70 & 16.97 & 288.00 & 326.70 & 350.70 & 24.00 & 5.01 \\
\hline 19 & $P C$ & Centre and West & 100 & 360.05 & 13.22 & 174.85 & 350.70 & 369.40 & 18.70 & 3.67 \\
\hline & & Total & 300 & 347.09 & 16.24 & 263.58 & 298.85 & 392.55 & 93.70 & 4.68 \\
\hline
\end{tabular}




\begin{tabular}{|c|c|c|c|c|c|c|c|c|c|}
\hline \multirow{4}{*}{20} & South & 100 & 286.05 & 16.19 & 262.21 & 274.60 & 297.50 & 22.90 & 5.66 \\
\hline & East & 100 & 272.88 & 12.48 & 155.76 & 264.05 & 281.70 & 17.65 & 4.57 \\
\hline & Centre and West & 100 & 290.83 & 12.90 & 166.53 & 281.70 & 299.95 & 18.25 & 4.44 \\
\hline & Total & 300 & 277.79 & 15.15 & 229.43 & 230.95 & 335.85 & 104.90 & 5.45 \\
\hline
\end{tabular}

Figures 2-5 graphically represent coeffi-cients of variation of studied anthropometric parameters.

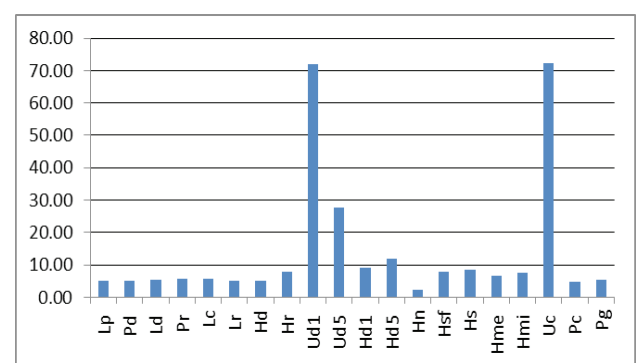

Figure 2. Distribution of coefficient of variation for TOTAL group

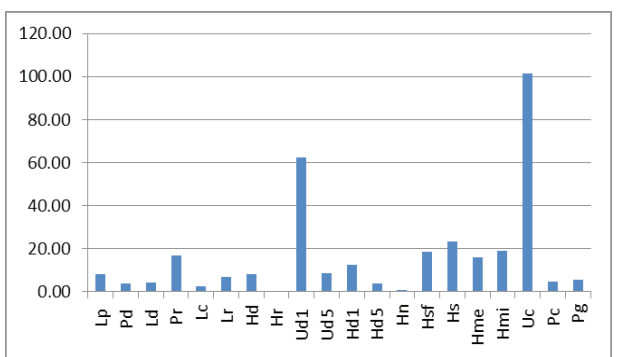

Figure 3. Distribution of coefficient of variation for SOUTH group

\section{One-dimensional Distribution}

The analytical form of distribution is $[3,13]$ :

$$
f(x, \mu, \sigma)=\frac{1}{\sigma \sqrt{2 \pi}} e^{-\frac{\left(x_{i}-\mu\right)^{2}}{2 \sigma^{2}}}
$$

where:

$f(x, \mu, \sigma)$-the frequency of finding particular values $x_{i}$ of variable $x$ within the selection;

$\mu_{x}$-arithmetic mean of variable $x$;

$\sigma^{2}, \sigma-$ scattering and standard deviation of variable $\mathrm{x}$;

$e=2.71828$ - the basis of the natural logarithm.

\section{Variational Sequence of Lp Variable (Foot Length)}

For the group of subjects, consisting of $n=300$, the distribution of the foot length (LP) variable is presented in Table 4. The values of the variational sequence are grouped into classes; for each class the absolute frequencies of the

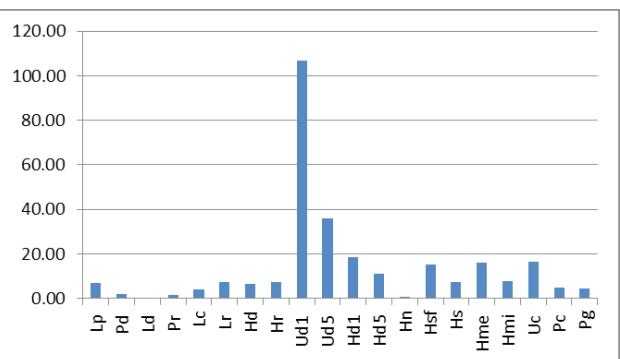

Figure 4. Distribution of coefficient of variation for EAST group

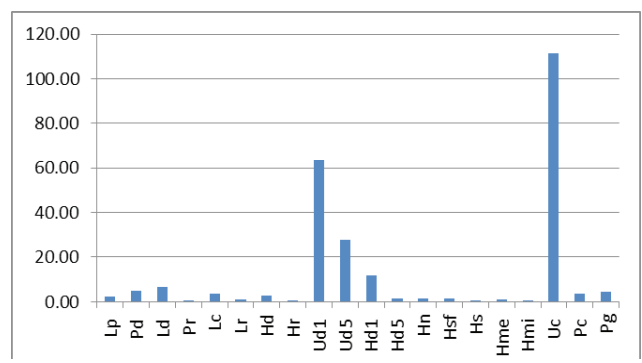

Figure 5. Distribution of coefficient of variation for WEST \& CENTRE group

Lp variable and the relative frequency of the selection volume were set.

Table 4: Distibution of Lp variable (foot length)

\begin{tabular}{llll}
\hline $\begin{array}{c}\text { Class interval } \\
(\mathrm{mm})\end{array}$ & $\begin{array}{c}\text { Class } \\
\text { centre }\end{array}$ & $\begin{array}{c}\text { Absolute } \\
\text { frequency }\end{array}$ & $\begin{array}{c}\text { Relative } \\
\text { frequency }(\%)\end{array}$ \\
\hline$<=242$ & & 10 & 3.33 \\
$242-247$ & 245 & 2 & 0.67 \\
$247-252$ & 250 & 26 & 8.67 \\
$252-257$ & 255 & 24 & 8.00 \\
$257-262$ & 260 & 42 & 14.00 \\
$262-267$ & 265 & 40 & 13.33 \\
$267-272$ & 270 & 48 & 16.00 \\
$272-277$ & 275 & 38 & 12.67 \\
$277-282$ & 280 & 34 & 11.33 \\
$282-287$ & 285 & 20 & 6.67 \\
$287-292$ & 290 & 8 & 2.67 \\
$292-297$ & 295 & 4 & 1.33 \\
$297-302$ & 300 & 2 & 0.67 \\
$>=302$ & & 2 & 0.67 \\
Total & & 300 & 100 \\
\hline
\end{tabular}


Figure 6 presents the histogram of absolute frequencies of $L p$ variable and the trend curve approximating the histogram.

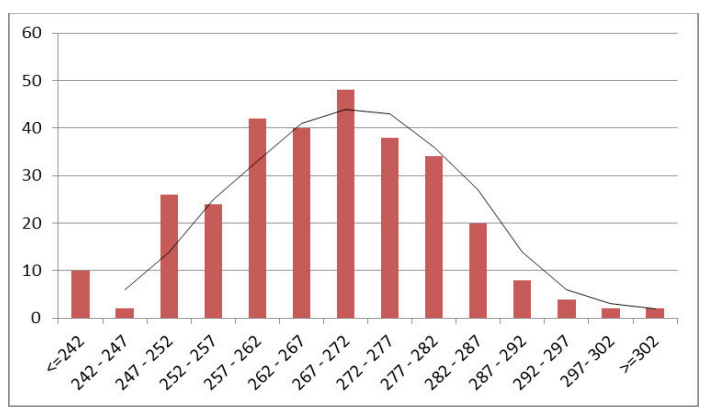

Figure 6. Distribution of absolute frequencies of Lp variable (foot length) and trend curve on class intervals for TOTAL group

\section{Variational Sequence of Pd variable (Toe Girth)}

Table 5 presents intervals of classes and absolute frequencies of $\mathrm{Pd}$ variable as well as the relative frequencies to the selection volume.

Table 5: Distribution of Pd parameter (toe girth)

\begin{tabular}{llll}
\hline $\begin{array}{c}\text { Class } \\
\text { interval } \\
(\mathrm{mm})\end{array}$ & $\begin{array}{c}\text { Class } \\
\text { centre }\end{array}$ & $\begin{array}{c}\text { Absolute } \\
\text { frequency }\end{array}$ & $\begin{array}{c}\text { Relative } \\
\text { frequency (\%) }\end{array}$ \\
\hline$<222$ & & 2 & 0.67 \\
$222-227$ & 225 & 0 & 0.00 \\
$227-232$ & 230 & 2 & 0.67 \\
$232-237$ & 235 & 6 & 2.00 \\
$237-242$ & 240 & 12 & 4.00 \\
$242-247$ & 245 & 18 & 6.00 \\
$247-252$ & 250 & 38 & 12.67 \\
$252-257$ & 255 & 40 & 13.33 \\
$257-262$ & 260 & 56 & 18.67 \\
$262-267$ & 265 & 28 & 9.33 \\
$267-272$ & 270 & 32 & 10.67 \\
$272-277$ & 275 & 32 & 10.67 \\
$277-282$ & 280 & 18 & 6.00 \\
$282-287$ & 285 & 8 & 2.67 \\
$287-292$ & 290 & 4 & 1.33 \\
$>292$ & & 4 & 1.33 \\
Total & & 300 & 100.0 \\
\hline
\end{tabular}

Figure 7 presents the histogram of absolute frequencies of $\mathrm{Pd}$ variable and the trend curve approximating the histogram.

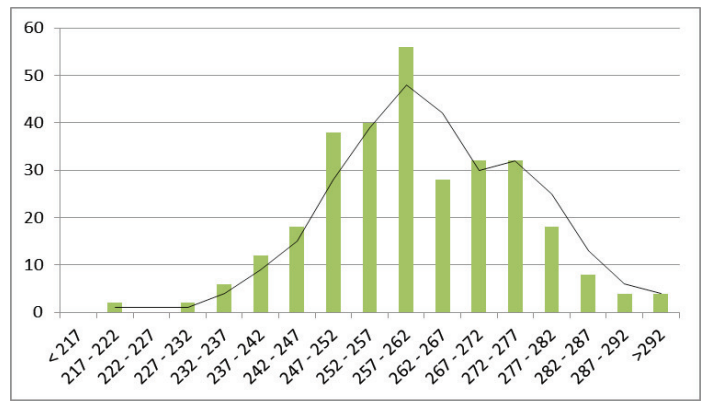

Figure 7. Distribution of absolute frequencies of $\mathrm{Pd}$ variable (toe girth) and trend curve on class intervals for TOTAL group

\section{CONCLUSIONS}

In order to verify the working hypothesis according to which there are no significant differences between the left foot and the right foot, Student's t-test and Fisher (F) test were used to check the variants. Both tests have shown that there are no significant differences between the left foot and the right foot for most anthropometric parameters. Furthermore, samples were made for the four groups studied based on the mean of anthropometric parameters of the right foot and the left foot.

Foot length (Lp) per total recorded an average of $267.43 \mathrm{~mm}$, with a coefficient of variation of $4.92 \%$. In the South and East, the average value is lower than the national average, while in the Centre-West region the average is significantly higher $(280.78 \mathrm{~mm})$. This implies that in the size series formation, in the South and East regions the frequency of the first series sizes is higher, while in the Centre-West region the frequency of the second series is higher.

Nationwide, toe girth has an average of $262.09 \mathrm{~mm}$. A value higher by $14.4 \mathrm{~mm}$ is recorded for the South region and $10.36 \mathrm{~mm}$ for the Centre-West region. In the Eastern region there is an average $\mathrm{Pd}$ value close to the national average $(258.95 \mathrm{~mm})$. The same situation is recorded for the foot breadth (Id). Since these two anthropometric parameters give the shoe width, it can be concluded that footwear for the 
South and Centre-West regions has to be made in larger sizes than the Eastern region.

Instep girth $(\mathrm{Pr})$ varies widely for the South region, where an average of $311.95 \mathrm{~mm}$ is recorded, well above the national average of $263.31 \mathrm{~mm}$. This entails restrictions on footwear models for this region that should be designed with adjustable straps to accommodate this large variation of the instep girth.

The heel width (Ic) shows coefficients of variation below $6 \%$ both at national level and at the level of each region. This justifies the standardization of the rear area of the last and the shoe components that structure this area (counter, heel, shank), thus reducing the cost of these components.

Instep length (Lr) has average values higher than the national average for the Centre region (202.73 mm versus $191.86 \mathrm{~mm}$ ). Also, instep height $(\mathrm{Hr})$ records the same trend.

$>$ Toe height $(\mathrm{Hd})$ is higher than the national average for the South region $(51.96 \mathrm{~mm}$ vs. $46.11 \mathrm{~mm}$ ). This situation also occurs in the case of toe 1 height ( $\mathrm{Hd} 1$ ) and toe 5 height (Hd5), respectively. This justifies the design of the last and the shoe so as to allow for a larger space and therefore a looseness in the toe area in the case of footwear made for the South region.

Anthropometric parameters of angle characterization (Ud1 - toe angle 1, Ud5 - toe angle 5 , and $U c$ - heel angle) have a very large scattering (the coefficient of variation is over $30 \%$ ). This demonstrates that very many subjects have deviations from the normal anatomical position of toes 1 and 5, and deviations of the heel, respectively. Most of the time, wearing a shoe improperly sized in the toe area (narrower or tighter) causes this situation. The worst situation is found in the eastern region where the coefficient of variation is very high, even compared to the national average. This is corroborated with the conclusion from the previous paragraph.

As far as the ankle girth $(\mathrm{Pg})$ and the heel girth $(\mathrm{Pc})$ are concerned, it is found that in the South and Centre-West regions the average values are higher than the national average, while in the Eastern region these parameters have smaller average values.

The normal one-dimensional distribution for anthropometric parameters such as foot length ( $L p)$ and toe girth (Pd) was verified. In this respect, the limits of the frequency classes, the centre of the class and the relative and absolute frequencies were established. This distribution is found in the commissioning of the shoe size series. For an optimal fit of footwear, it is necessary to divide the size series into length and width classes.

\section{Acknowledgements}

This work was financed by the Romanian Ministry of Research and Innovation in the framework of Nucleu Program Inova-Tex-Pel, 2016-2017, project code PN 16340401.

\section{REFERENCES}

1. Pantazi, M., Vasilescu, A.M., 3D Imaging Capture of the Foot and Data Processing for a Database of Anthropometric Parameters, Proceedings of The $6^{\text {th }}$ International Conference on Advanced Materials and Systems - ICAMS 2016, ISSN: 2068-0783, CERTEX Press, Session 3 Innovative Technologies, 2016, 387-392.

2. Avadanei, M., Theoretical and Experimental Contributions on the Use of Antropometric Data in Designing Clothing Items (in Romanian), PhD Thesis, "Gh. Asachi" Technical University of Iasi, 2000.

3. Gheorghiu, D., Statistics Applied in Psychology (in Romanian), Bucharest, "Titu Maiorescu" University Press, ISBN 973-86202-28, 2003.

4. Radu, E., Adam, M., Gaghes, R., Anthropological Indicators of Medical Relevance, Studies and Research in Anthropology (in Romanian), vol. 24, 1987, 19-30.

5. Erdemir, A. et al., Local Plantar Pressure Relief in Therapeutic Footwear: Design Guidelines from Finite Element Models, Journal 
of Biomechanics, 2005, 38, 9, 1798-806, https:// doi.org/10.1016/j.jbiomech.2004.09.009.

6. Patterson, R.P., Shoes and the Army, statement issued June 4, 1945, The Quartermaster Review, July-August 1945.

7. Raulea, C., Psychological Statistics and Computerized Data Processing - Introductive Course (in Romanian), 2010.

8. Taloi, D., Optimization of Metallurgic Processes (in Romanian), Didactic and Pedagogic Press, Bucharest, 1983.

9. Ujevic, D., Theoretical Aspects and Application of Croatian Anthropometric System (CASE), University of Zagreb, Faculty of Textile Technology, Croatia, ISBN 978-9537-105-28-0, 2010.

10. Mochimaru, M., Kouchi, M., Dohni, M., Analysis of 3D Human Foot Forms Using the FFD Method and its Application in Grading Shoe Last, Ergonomics, 2000, 43, 9, 1301-1313.
11. Nácher, B., Alemany, S., González, J., Alcántara, E., A Footwear Fit Classification Model Based on Anthropometric Data, SAE Technical Paper, 2006-01-2356, 2006.

12. Ujevic, D., K. Doležal, R., Hrženjak, B., Croatian Anthropometric System, TEDI Vol 1, 2011, 40-48.

13. Gheorghiu, D., Psychological Statistics and Computerized Data Processing (in Romanian), Bucharest, 2005.

(C) 2017 by the author(s). Published by INCDTPICPI, Bucharest, RO. This is an open access article distributed under the terms and conditions of the Creative Commons Attribution license (http:// creativecommons.org/licenses/by/4.0/). 